\title{
Comparison of Larger Diameter and Multiple Cysts in the Treatment of Giant Hydatid Cysts of Liver
}

\author{
Karaciğer Dev Kist Hidatiklerinin Tedavisinde Büyük Çaplı ve Multipl Kistlerin Karșılaștırılması
}

\section{Mehmet Aziret', Hilmi Bozkurt², Hasan Erdem², Sahin Kahramanca', IIhan Bali³ , Enver Reyhan², Safa Önel ${ }^{2}$, Kenan Binnetoğlu ${ }^{4}$, Ali Cihat Yıldırım', Oktay İrkörücü ${ }^{2}$}

${ }^{1}$ Kars State Hospital, Department of General Surgery Kars, Turkey; ${ }^{2}$ Adana Numune Training and Research Hospital, Department of General Surgery, Adana, Turkey; ${ }^{3}$ Firat University Faculty of Medicine, Department of General Surgery, Tekirdağ, Turkey; ${ }^{4}$ Firat University Faculty of Medicine, Department of General Surgery, Elazı̆g, Turkey

\begin{abstract}
AIM: Hepatic hydatidosis is a benign, chronic parasitic disease that can affect many organs. The disease is usually asymptomatic, but the cysts that develop as a result of the disease can reach large sizes. We aimed to compare large hydatid cysts $(>10 \mathrm{~cm})$ and multiple cysts (>4) in giant hydatid cysts of liver in terms of demographic structure, recurrence, complications, diagnosis and treatment.

METHODS: A total of 15 out of pool of 62 patients were enrolled in the study and placed into two groups: Group 1 included patients with a cyst diameter larger than $10 \mathrm{~cm}(n=12)$ and Group 2 included patients with more than 4 cysts $(n=3)$. The two groups were retrospectively compared in terms of age, sex, demographic structure, recurrence, complications, morbidity and mortality, diagnosis and treatment.

RESULTS: In Group 1, the patients' mean age, BMI, diameter of cyst and hospitalization time, were 39.5 years, $25.5 \mathrm{~kg} / \mathrm{m} 2,11.75$ $\mathrm{cm}, 9.8$ days and 21.4 months, respectively. In Group 2, the patients' mean age, BMI, number of cysts and hospitalization time were 44.7 years, $27.7 \mathrm{~kg} / \mathrm{m} 2,8.3$ cysts, 8.6 days and 17.1 months, respectively ( $p>0.05)$. In Group 1, 1 patient had a wound infection (1.6\%) and 1 patient had an intraoperative hemorrhage (1.6\%). In Group 2, 2 patients had recurrence (3.2\%). A significant difference was detected between groups in terms of recurrence $(p=0.029)$.

CONCLUSION: Rarely seen, giant hydatid cysts may cause secondary infection or fistulization into several organs, and it can open into the peritoneal cavity or place pressure on adjacent organs and structures, which leads to obstructive jaundice. Morbidity, mortality and cost can increase should these potential results of giant hydatid cysts occur. This study demonstrated the resulting high rate of cure and low morbidity and complications that were able to be achieved using conservative surgical treatment methods for hydatid cysts.
\end{abstract}

Key words: giant hydatid cyst; echinococcus granulosus; conservative surgical treatment

Uzm. Dr. Mehmet Aziret, Sakarya Üniversitesi Ĕgitim ve Arașttrma Hastanesi, Genel Cerrahi Kliniği, Sakarya, Türkiye, Tel. 05063057317

Email.mbmtaziret@gmail.com

Gelis Taribi: 22.10.2014 • Kabul Tarihi: 23.07.2015

\section{ÖZET}

AMAÇ: Karaciğer kist hidatiği benign, kronik ve birçok organı etkileyebilen paraziter bir hastalıktır. Çoğunlukla asemptomatiktir ve büyük boyutlara ulașabilir. Dev karaciğer kist hidatiklerinde büyük çaplı (>10 cm) ve multipl sayıda (>4) hastaların tedavi, nüks, morbidite ve mortalite, sosyodemografik yapı ve komplikasyonlarını karșılaștırmayı amaçladık.

YÖNTEM: Toplam 62 hastanın 15 tanesi çalıșmaya dahil edildi. Çalıșmada iki grup olușturuldu. Grup 1, kistin çapı 10 cm'den büyük hastalar ( $n=12)$; Grup 2, kist sayısı 4'ten fazla hastalardı $(n=3)$. iki grup, komplikasyon, nüks, sosyodemografik açıdan, tanı ve tedavileri açısından istatistiksel olarak karșılaștırıldı. Çalıșma retrospektif olarak planlandı.

BULGULAR: Grup 1'de hastaların sırasıyla ortalama yaș, vücut kitle indeksi, kist çapı, hastanede kalma süresi, takip süresi; 39, 5 yıl, 25, $5 \mathrm{~kg} / \mathrm{m2}, 11,75 \mathrm{~cm}$, 9,8 gün, 21, 4 aydı. Grup 2'de hastaların sırasıyla ortalama yaș, vücut kitle indeksi, kist sayısı, hastanede kalma süresi, takip süresi; 44,7 yıl, 27,7 kg/m2, 8,3 adet, 8,6 gün, 17,1 aydı ( $p>0,05)$. Grup 1'de, 1 hastada yara enfeksiyonu, 1 hastada intraoperatif kanama ve Grup 2'de 2 hasta da nüks görüldü. Nüks açısından iki grubun karșılaștırmasında anlamlı farklıık tespit edildi $(p=0,029)$.

SONUÇ: Dev kist hidatikler toplumda nadir görülmektedir. Çevre organ ve yapılara bası, safra yollarına veya peritona açılma ve anafilaktik șoka neden olabilmektedir. Ayrıca morbidite, mortalite ve hastane maliyelerini artırabilmektedir. Çalıșmamızdaki bulgular sonucunda dev kist hidatiklerine konservatif cerrahi yöntemleriyle, yüksek kür ve düșük morbidite ve komplikasyon oranlarıla etkin tedavi edilebilmektedir.

Anahtar kelimeler: dev kist hidatik; ekinokokus granulosus; konservatif cerrahi tedavi 


\section{Introduction}

A hydatid cyst (HC) is produced from hepatic hydatidosis, aparasitic disease caused by the cestoda Echinococcus granulosus (EG) $)^{1-3}$. HCs are mostly seen in the liver (70\%) in humans ${ }^{3,4}$. Dogs and wolves are the primary hosts for EG, while humans, sheep and cattle are intermediate hosts 5 . Cases of hydatid cyst are usually found in South Australia, New Zealand, Africa, Greece, Spain, and the Middle East. Its annual incidence is $2-6 \%$ in endemic regions ${ }^{6}$.

Because hydatid cystsare generally asymptomatic, diagnosis often comes late, usually not until the cyst grows and increases in diameter. Significant complications are associated with giant HCs, such as the cyst's penetration into other organs, cholangitis and anaphylactic shock. High morbidity and mortality may result from these complications ${ }^{2-4,6}$.

Serologic tests, such asthe enzyme-linked immunosorbent assay (ELISA) and the indirect hemagglutination test (IHA), can be used for diagnosis of $\mathrm{HC}$. Additionally, abdominal ultrasonographies (USG), computer tomographies (CT) and magnetic resonance imaging (MRI) are quite sensitive for detecting hydatid cysts ${ }^{7,8}$. A sonography classification of the cyst can greatly aid the diagnosis and treatment of $\mathrm{HC}$. Over time, the classification of HC has changed, with the most recent one being issued by the WHO-IWGE (World Health Organization-Informal Working Group on Echinococcosis), which classifies HC stages as active (CE1 and CE2), transitional (CE3) and inactive (CE4 and CE5) (Fig. 1) $)^{9-11}$.

In this study, we aimed to compare large hepatic hydatid cysts (diameter $\geq 10 \mathrm{~cm}$ ) and multiple cysts $(>4)$ in giant hydatid cysts in terms of diagnosis, treatment, complications and recurrence rates.

\section{Materials and Methods}

\section{Ethics Statement and Patients}

All patients gave their written informed consent to data treatment and the study was approved by the Ethics Committee. The sixty-two patients who were diagnosed with $\mathrm{HC}$ in the liver and underwent surgical treatment for it between January 2012 and September 2014 at the Adana Training and Research Hospital and the Kars state hospital, department of general Surgery were analyzed to determine recurrence, complications and socio-demographic data and followed up. Forty-seven patients were excluded from the study due to diameter of their cysts being $<10 \mathrm{~cm}$ or their number of cysts being $<4$. As a result, fifteen patients were included in study. The study was retrospective in design, with no randomization. The $15 \mathrm{pa}-$ tients who had been treated with surgery for $\mathrm{HC}$ were divided into the following two groups for treatment: Diameter of cysts larger than $10 \mathrm{~cm}$ (larger diameter cysts) (Group 1$)(\mathrm{n}=12)$ and number of cysts $>4$ (multiple cysts) (Group 2) ( $n=3)$ (Table 1). All cases were evaluated in terms of gender and age, location of liver, postoperative length of hospital stay, postoperative complications (wound dehiscence, infection, hematoma, seroma) and recurrence. Before the treatment, all the diagnoses were confirmed by radiological examinations (ultrasonography and/or computed tomography or MRI) and indirect hemagglutination (IHA) with antigen test. In cases of suspicion of a cystobiliary fistula $(\mathrm{CBF})$, a magnetic resonance cholangiopancreatography (MRCP) or endoscopic retrograde cholangiopancreatography (ERCP) was performed to investigate the biliary duct obstruction. All of the patients were treated with albendazol before $(10-15 \mathrm{mg} /$ $\mathrm{kg} /$ day for 3 weeks) and after $(10-15 \mathrm{mg} / \mathrm{kg} /$ day in a

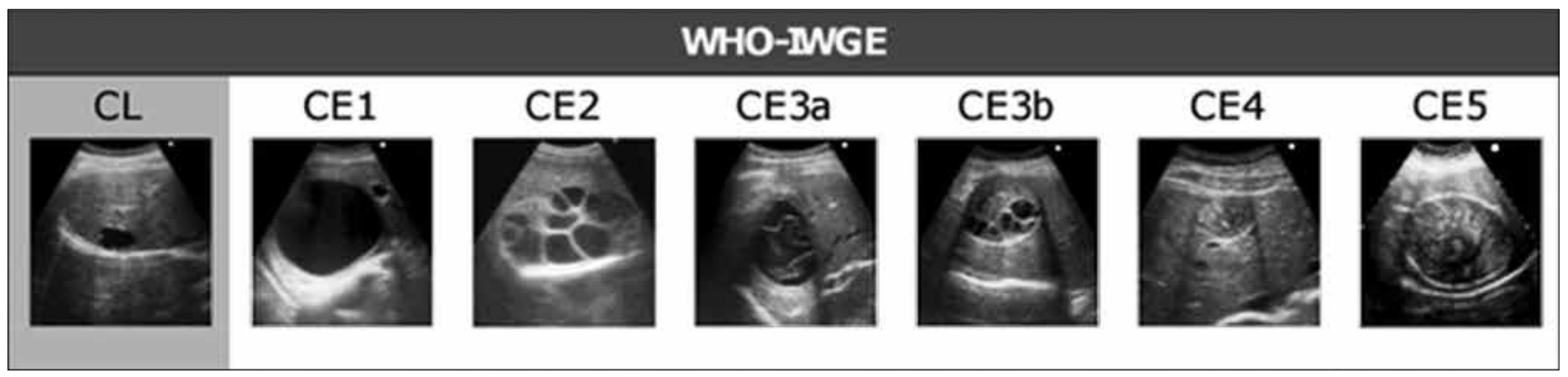

Figure 1. WHO-IWGE ultrasound classification of echinococcal cysts. CE1 and CE2 (active cysts), CE3A and CE3B (transitional cysts), and CE4 and CE5 (inactive cysts). doi:10.1371/journal.pntd.0003057.g001 
course of 6 months, separated by intervals of 1 week) the invasive approaches. The patients' liver functions were evaluated every month.

\section{Inclusion Criteria}

1- Patients willing to give written informed consent.

2- Adult patients (over 18 years of age) undergoing surgery for $\mathrm{HC}$.

3- Diameter of cysts $>10 \mathrm{~cm}$.

4- Number of cysts $>4$.

5- Active period for the HC (CE1, CE2 and CE3).

6- International normalizing ratio (INR) $<1.5$.

7- Prothrombin time (PT) should be $<15 \mathrm{~s}$.

8- Partial thromboplastin (PTT) time should be near normal.

9- Platelet count should be $>50,000 / \mathrm{mm}^{3}$ to limit the risk of bleeding.

Table 1. Patients and cyst characteristics

\begin{tabular}{|c|c|c|c|}
\hline Characteristics & $\begin{array}{c}\text { Diameter of cysts } \\
>10 \mathrm{~cm} \\
(\mathrm{n}=12)\end{array}$ & $\begin{array}{c}\text { Number of cysts } \\
>4 \\
(n=3)\end{array}$ & $\mathrm{p}$ value \\
\hline Gender $\mathrm{M} / \mathrm{F}$ & $6 / 6$ & $1 / 2$ & 1 \\
\hline Mean age (years) & 39.5 & 44.60 & 0.563 \\
\hline $\mathrm{BMl}\left(\mathrm{kg} / \mathrm{m}^{2}\right)$ & 25.5 & 27.6 & 0.384 \\
\hline \multicolumn{4}{|l|}{ Symptoms } \\
\hline Abdominal pain (\%) & 44 & 54 & - \\
\hline Nausea (\%) & 18 & 10 & - \\
\hline Nonspecific (\%) & 15 & 7 & - \\
\hline Asymptomatic & 33 & 29 & - \\
\hline Mean cyst size $(\mathrm{cm})$ & 11.75 & - & \\
\hline Mean number of cysts & - & 8.3 & \\
\hline \multicolumn{4}{|l|}{ Side } \\
\hline Left & 3 & 0 & \\
\hline Right & 8 & 0 & \\
\hline Bipolar & 1 & 3 & \\
\hline IHA (\%) & 68.4 & 72.5 & 0.343 \\
\hline Mean hospital stay (day) & 9.8 & 8.6 & 0.767 \\
\hline Follow up (months) & 21.4 & 17.1 & 0.248 \\
\hline
\end{tabular}

\section{Exclusion Criteria}

1- Patients not willing to give informed consent

2- $<16$ years of age.

3- Diameter of cysts $<10 \mathrm{~cm}$.

4- Number of cysts $<4$.

5- No active period for the HC (CL1, CE4 and CE5) and emergency cases.

6- Uncontrolled diabetes mellitus, renal failure, coagulation and immunosuppression disorders.

\section{Surgical Technique}

All patients were operated on under general anesthesia in the operating room. After administration of anesthesia, standard aseptic procedures were performed before the laparotomy.In most patients, entry was made into the abdomen through a right subcostal incision, with the incision having to be extended in only few patients. Hypertonic saline gas compresses $(3 \% \mathrm{NaCl})$ or povidone-iodine $10 \%$ solution was prepared before surgery. The hypertonic solution was injected into cysts according to their diameter. The cyst was opened after approximately 15 minutes. Total/partial pericystectomy, cystotomy and drainage, $\mathrm{T}$ tube or simple suture, unroofing, introflexion, capitonnage and/or omentoplasty were the preferred procedures, and the appropriate technique was performed according to the characteristics of patient's cyst. Drain was placed according to the state of cyst after washing with $0.9 \% \mathrm{NaCl}$. Abdomen was closed anatomically (Fig. 2 and Fig. 3).

\section{Serology}

The indirect hemagglutination test (IHA) performed on all of our patientswas made in the laboratory of our hospital, according to the manufacturer's instructions. IHA was also performed to evaluate recurrence and to conduct postoperative follow up.

\section{Postoperative Follow-up}

The patients were evaluated using serological tests and either USG, CT scan or MRI at intervals of three months in the postoperative first year. Complete blood count $(\mathrm{CBC})$ and liver function tests were performed every month for the first 6 months. In cases when high liver function tests were administered, Albendazol or Mebendazol was stopped. All patients were provided with the hospital telephone numbers to call in case of emergency. 

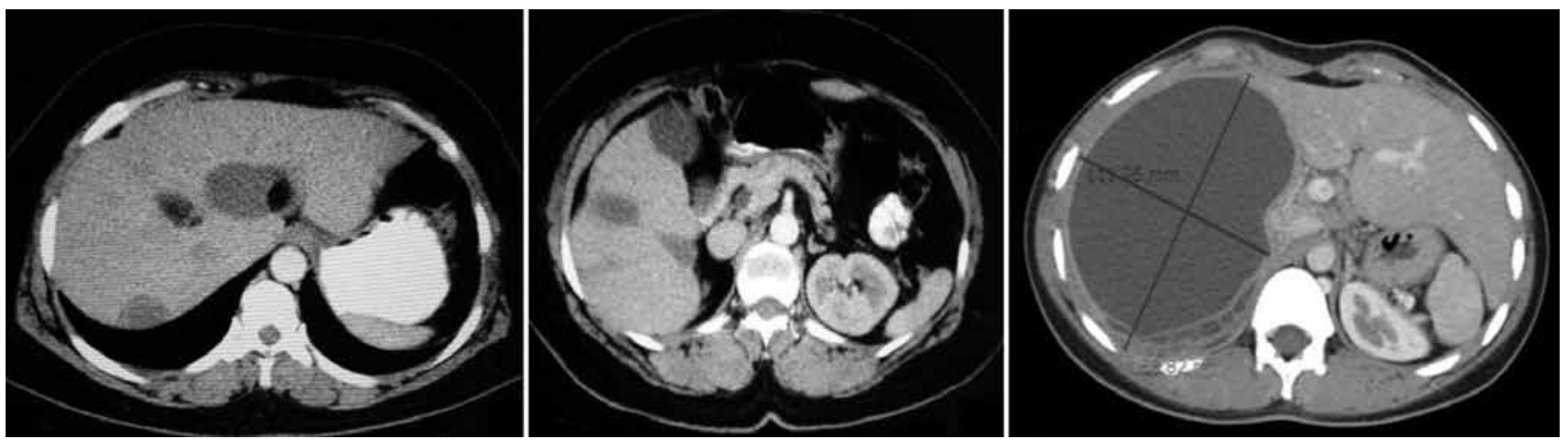

Figure 2. Appearance of large diameter cysts and multiple cysts in computed tomography scan. Multiple cysts in different sections (left and middle) of the same patient. Giant hydatid cyst (right).
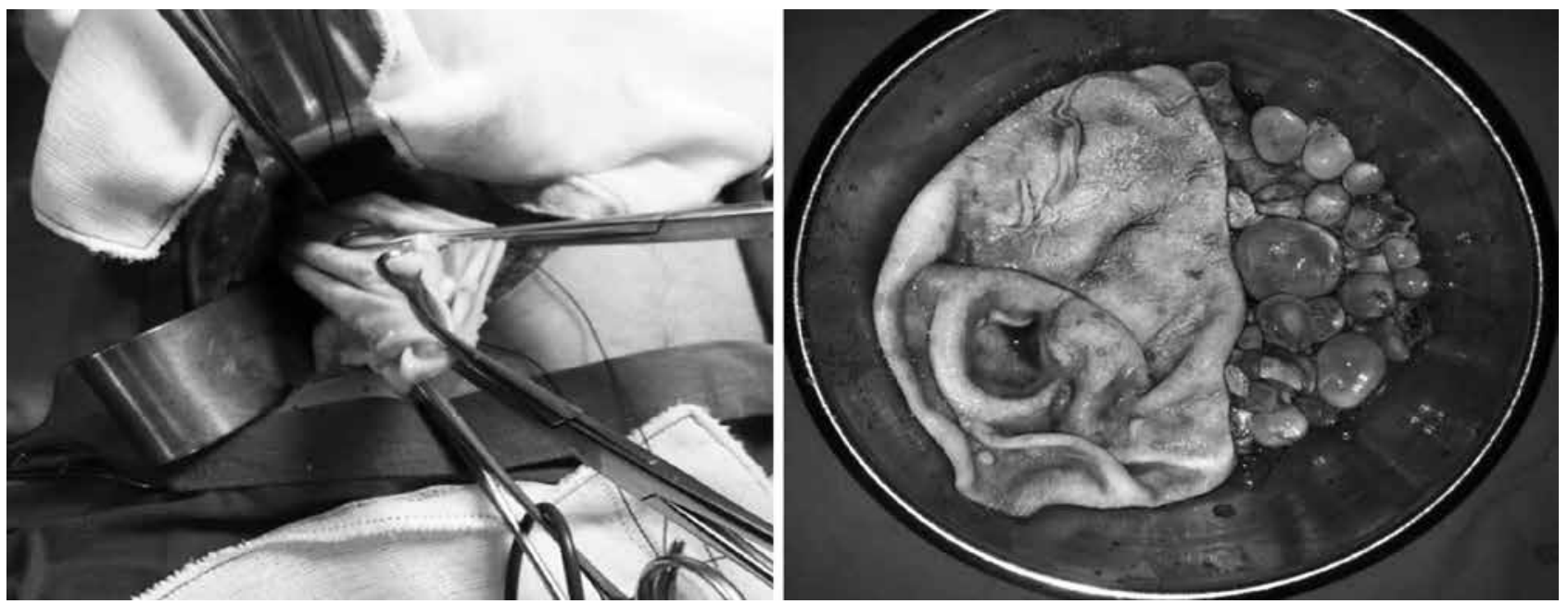

Figure 3. Appearance of cyst at removal and daughter cysts, cyst wall and germinal membrane.

\section{Statistical Analysis}

The data compiled in this study were analyzed through SPSS 20 software package (Statistical Package for the Social Sciences ver. 20.0, SPSS Inc, Chicago, Illinois, USA). Chi-square analysis was used for assessment of frequency distributions, and the Mann-Whitney $U$ and Fisher's Exact tests were used for comparisons of mean values. For all statistical analyses $\mathrm{p}<0.05$ was accepted as significant.

\section{Results}

There was no mortality in any of our patients. A total of $7(46.7 \%)$ patients were male and 8 (53.3\%) female in this study, and no statistically significant differences were found between the two groups in terms ofgender ( $p>0.05)$. The mean age of the patients was $41.05 \pm 4.3$ years, withthe minimum and maximum ages being 19 and 70 years old. In Group 1, the mean age of the patients was 39.5 years, and in Group 2, it was 44.7 years. The patients in Group 2 were older than those in Group 1, but no statistically significant differences were found between the groups in terms of age ( $p>0.05)$. In Group 1, 12 patients had cysts with a diameter larger than $10 \mathrm{~cm}(80 \%)$, and 3 patients in Group 2 had more than 4 cysts (20\%). The body mass index (BMI) was 25.5 and $27.7 \mathrm{~kg} / \mathrm{m}^{2}$ in Group 1 and Group 2, respectively $(p>0.05)$. Patients from both groups experienced pain in the upper right quadrant $-44 \%$ in Group 1, and $54 \%$ in Group 2 - while some patients had multiple complaints. In Group 1, 33\% of the patients were asymptomatic and in Group 2, 29\% were asymptomatic. Most of the cysts were located in the right hepatic lobe (55.4\%), 4 of the patients had multiple and bilobar cysts and 1 patient had a cyst in the left lobe (Table 1 ). The mean cyst size in Group 1 was $11.75 \mathrm{~cm}$ and the mean number of cysts in Group 2 was 8.3. 
The mean hospitalization time was similar between each group ( 9.8 and 8.6 days, respectively), and no statistically significant differences were found between the two groups in terms of mean hospitalization time $(p>0.05)$. The median follow-up time of patients was 25.6 months (total 9,250 days) (Table 1). Intraoperative massive hemorrhage occurred in one of the patients when removing the cyst from the left hepatic vein. The patient was administered 8 units of erythrocyte suspension and 8 units of fresh frozen plasma intraoperatively. The patient was taken to the intensive care unit with a mechanic ventilator. Wound infection also occurred in the same patient.

During the follow-up period, 2 recurrences (13.3\%) occurred in Group 2. No recurrences, however, occurred in Group 1, and significant differences were found between the groups in terms of recurrence $(p=0.029)$. Wound infection occurred in 1 patient in Group 1 and in 2 patients in Group 2. No significant differences werefound between the groups in terms of wound infection $(p>0.05)$. Perihepatic abscess, incisionel hernia, postoperative biliar fistula and mortality did not occur in any patients (Table 2).

All of the cysts were classified according to both the WHO-IWGE classification of HC and the Gharbi classification. One patient had CE1, 7 patients had CE2, 5 patients had CE3a, 1 patient had CE4 and 4 patients had CE3b. Two patients had both CE2 and CE3a in Group 2 and one patient had CE3a and CE4 at the same time in Group 2. CL1 and CE5 were not determined in either of the two groups' patients who underwent a laparotomy (Table 2).

Conservative surgical treatments were performed in the two groups. Onepatient underwent drainage and omentoplasty, 3 patients underwent drainage and cysto-pericystectomy, four patients underwent drainage, cysto-pericystectomy and omentoplasty, two patients underwent drainage, cysto-pericystectomy and capitonnage, one patient underwent drainage, cysto-pericystectomy and introflexion, one patient underwent drainage, cysto-pericystectomy and simple suture and two patients underwent drainage, cysto-pericystectomy and T-Tube drainage (Table 3 ).

\section{Discussion}

Hepatic hydatidosis, which is responsible for producing hydatid cysts in the host, is known as one of the oldest diseases and was referred to as liver filled with
Table 2. Complications

\begin{tabular}{lccc}
\hline & Group 1 & Group 2 & P value \\
\hline Wound infection & 1 & 2 & 0.224 \\
Hemorrhage & 1 & 0 & 0.056 \\
Recurrence & 0 & 2 & 0.029 \\
Mortality & 0 & 0 & \\
\hline
\end{tabular}

Table 3. WHO-IWGE classification and surgical methods

\begin{tabular}{|c|c|c|}
\hline Diagnosis and treatment & $\begin{array}{l}\text { Diameter of cysts } \\
>10 \mathrm{~cm}\end{array}$ & $\begin{array}{c}\text { Number of cysts } \\
>4\end{array}$ \\
\hline \multicolumn{3}{|l|}{ WHO-IWGE classification } \\
\hline CE1 & 1 & 0 \\
\hline CE2 & 5 & 2 \\
\hline CE3a & 3 & 2 \\
\hline CE3b & 3 & 1 \\
\hline CE4 & - & 1 \\
\hline \multicolumn{3}{|l|}{ Surgical methods } \\
\hline Drainage +0 & 1 & 0 \\
\hline Drainage $+C-p$ & 2 & 1 \\
\hline Drainage $+C-p+0$ & 4 & - \\
\hline Drainage $+C-p+C$ & 1 & 1 \\
\hline Drainage $+C-p+1$ & 1 & - \\
\hline$D+C-p+$ Simple sutur & 1 & - \\
\hline$D+C-p+T$-Tube drainage & 2 & - \\
\hline
\end{tabular}

water' by Hippocrates ${ }^{12}$. The Turkana region of Kenya features the most cases of hydatid cysts (200/100.000) in the world ${ }^{13}$. The annual incidence rate in Turkey is $4.4-6.5 / 100,000$ and giant hydatid cysts are rarely $\operatorname{seen}^{14}$. HC is observed slightly more in women than in man (female $\geq \operatorname{man})^{15}$. In our study, the rate of women with $\mathrm{HC}$ was $53.3 \%$.

$\mathrm{HC}$ results from a chronic disease caused by infection from Echinococcus granulosus, Echinococcus multilocularis, Echinococcus vogeli, and Echinococcus oligarthrus. Echinococcus granulosus (EG) is the most common cause of $\mathrm{HC}$ and is largely localized in the liver ${ }^{14,15}$. It can also be found, less frequently, in the lung, spleen, kidney and brain ${ }^{16}$. HC often occurs with uncontrolled slaughter and is taken by directly or indirectly diseased organs ${ }^{17}$. Our study was in agreement with the clinical picture described above. 
The majority of $\mathrm{HC}$ cases are asymptomatic, but when symptoms do appear, they include upper right quadrant pain, nausea, vomiting, jaundice and fever ${ }^{18}$. Because of the slow growth rate of cysts $(1-2 \mathrm{~cm} /$ year $)$ in the host and the lack of symptoms accompanying them, cysts can reach to large sizes before being diagnosed and possibly fistulize into the bile ducts when the diameter of the cyst increases ${ }^{18,19}$. The incidence of asymptomatic patients in various series is $8-75 \%$. In our patients, the primary symptom seen was upper right quadrant pain. Additionally, the mean diameter of cysts in patients was $11.3 \mathrm{~cm}$ and in three patients biliary fistulas developed.

Imaging techniques and serology can help in the diagnosis of HC. The sensitivity of an enzyme-linked immunosorbent assay (ELISA) is $64-100 \%{ }^{20}$. In the study carried out by Piccoli et al. the rate of negative sensitivity was detected to be $70 \%$ for ELISA in diagnosis ${ }^{9}$. The sensitivity of the indirect hemagglutination test (IHA) was $64-100 \%^{7,20}$. In our patients, the sensitivity of IHA was approximately $70 \%$ and no significant difference was found between the two groups in terms of this test $(\mathrm{p}>0.05)$.

Ultrasonography is frequently used in the diagnosis, treatment and follow-up of $\mathrm{HC}$, with rates of correct diagnosis at 90\%,21. CT scan and MRI are effective in terms of identifying hydatid disease, detecting complications and determining non-liver HC locations ${ }^{22}$. CT scan and USG were used in the diagnosis of all our patients, while MRI was used in only some of them.

The Gharbi and WHO-IWGE classifications are used for the management of diagnosis and treatment of HC. The Gharbi classification shows the natural course of the disease and the WHO-IWGE determines activity and viability of cyst (Fig. 1) $)^{10,11}$. All of our patients had classification of active period HC (CE1, CE2 and CE3).

The treatment course for $\mathrm{HC}$ includes medical treatment, follow-up, percutaneous aspiration and drainage and laparoscopic and open surgery ${ }^{22,23}$. The most important issue to address when dealing with HCs involves determining which cysts to treat. Medical treatment can vary depending on the unique circumstances of each patient. For example, non-surgical treatment is preferred in patients who are older or pregnant, when co-morbidities are present or when the cyst is located in a hard to reach locationfor the performance of surgical or percutaneous treatment ${ }^{23,24}$. Additionally, the treatment is not generally recommended in Type 5 or CE4 and CE5 classifications. Albendazol (10-15 mg/ $\mathrm{kg} /$ day) or Mebendazol (35-50 mg/kg/day) may be administered to patients as treatment for a period of 4-6 months but patients should be monitored with liver function tests. However, inpatients with symptomatic and active period cysts, treatmentshould be given due to risk of severe complications ${ }^{24}$. The goal of treatment is to prevent secondary infection as well as to prevent the cyst from fistulizing into other organs, opening into the peritoneal cavity and putting pressure on adjacent organs and structures, which leads to obstructive jaundice ${ }^{25,26}$.

PAIR (puncture, aspiration, injection and re-aspiration), which was defined by Amour in 1986, is usually recommended in Type 1 and 2, and some Type 3 classification cysts ${ }^{27}$. In a meta-analysis conducted on PAIR, it was reported that the rates of cure were $95 \%$, mortality $0.1 \%$, recurrence $1.6 \%$, minor complications $13.1 \%$ and major complications $7.9 \%^{28}$. Although the use of PAIR was encouraged in the Cochrane systematic review, the review also indicated that there was insufficient evidence to support its effectiveness and that there was a need for well-designed randomized controlled trials to further confirm its validity ${ }^{29}$.

Laparoscopic surgery is used in the treatment of $\mathrm{HC}$. As this surgery is minimally invasive and low cost, is can be used as a viable option. However, it should be noted that there are limitations associated with this option, namely, the possibility of contamination of the cyst into the abdominal cavity ${ }^{30}$.

Radical surgical procedures, such as lobectomy or hepatectomy, have recently been increasingly used in the treatment of hepatic $\mathrm{HC}$, and it has been reported that these procedures have low recurrence, morbidity and mortality rates ${ }^{31,32}$. For example, in the meta-analysis conducted by Buttenscho et al. the rates of mortality were reported to be $1.2 \%$, morbidity $11.7 \%$ and recurrence $2 \%{ }^{25}$. However, many researchers argue that it is unnecessary to perform radical interventions forbenign diseases. Therefore, we chose to perform conservative surgery in our patients (Fig. 3).

Conservative surgical approaches include drainage of cavity, cyst-pericystectomy, omentoplasty, capitonnage or introflexion, T-Tube drainage and simple suture for biliary fistula ${ }^{16,21,26,29,32}$. Jerraya et al. reported rates of cure to be $90 \%$, mortality $0.7 \%$ and recurrence $6 \%$ with conservative approaches for $\mathrm{HC}^{32}$. In our 
study, the conservative surgery methods we usedon patients resulted in rates of recurrence of $3.2 \%$, cure $95 \%$, mortality $0 \%$ and morbidity $9.6 \%$. The data from our study are similar with the data found in the literature $^{25,28,32}$. In Group 2, 2 cases of recurrence occurred, with statistically significant differences found between large cysts and multiple cysts groups in terms of recurrence $(p<0.05)$. These results suggest that conservative treatment may be limited in cases of multiple HC. However, in 1 of our patients who had a giant cyst, a left hepatectomy was planned, but massive intraoperative hemorrhaging occurred, and therefore, drainage of cavity, cyst-pericystectomy and omentoplasty were performed on the patient. As a result, in patients with giant cysts, radical surgery combined with a multidisciplinary approach should be considered, particularly in high volume centers.

When the number of $\mathrm{HC}$ or the diameter of $\mathrm{HC}$ increases, the rate of complications tends to increase with time. In a study by Milicevic et al. conducted onthe connected biliary ducts of patients, it was reported that $70 \%$ of the biliary ducts were connected and that they were controlled with simple suture ${ }^{18}$. In the same study, T-tube drainage was performed on $16 \%$ of the patients and a Roux-en-Y cystojejunostomy on $2 \%$ of the patients. Gonzales et al. suggested that a Roux-en-Y cystojejunostomy and sphincteroplasty should be performed for large hydatid cysts $(>20 \mathrm{~cm})$ in cases of biliary fistulas ${ }^{19}$. Darakdeh et al. reported that surgical treatment had negative effectsin cases when the diameter of cyst was wider than $10 \mathrm{~cm}$, the patient was older than 40 years of age and preoperative complications were pres$\mathrm{ent}^{31}$. In our study, the biliary fistula was found in $3 \mathrm{pa}-$ tients, 1 of the them was treated with a primary suture and other two patients were treated with T-tube drainage. In follow-ups on these patients, no biliary fistula was present and recurrence did not occur. Finally, Elber et al. demonstrated in their study comparing T-tube drainage and choledochoduodenostomy that tube drainage was more effective ${ }^{33}$. With these results, it can be suggested that primary suture and T-tube drainage are effective treatments for biliary fistula.

Our study did include some limitations. Firstly, because giant HCs are rare, we had an insufficient number of patients and therefore, randomization was unable to be achieved. Secondly, since the literature lacks evidence from high-value studies, adequate comparisons were unable to be made. Lastly, our follow-up period was not long enough to clearly evaluate recurrence.

\section{Conclusion}

Giant hydatid cysts are rare and benign cysts of liver. They should be treated early to prevent the onset of fatal complications. In our study, giant hydatid cysts were successfully treated with conservative surgical methods and our results were similar to those found in the literature.

\section{Acknowledgments}

This study was not supported by any company and it was presented as the oral presentation at the 3 th National Surgery of Gastroenterology congress.

\section{Conflicts of Interest}

There are not any conflicts of interest.

\section{References}

1. Fernández-Martínez D, Alvarez-Pérez JA, Granero-Castro P, et al. Giant hepatic hydatid cyst with mediastinal extension. Rev EspEnferm Dig 2013;105(6):367-8.

2. Rinaldi F, De Silvestri A, Tamarozzi F, et al. Medical treatment versus "Watch and Wait" in the clinical management of CE3b echinococcal cysts of the liver. BMC Infect Dis 2014;14:492.

3. Craig PS, Larrieu E. Control of cystic echinococcosis/ hydatidosis: 1863-2002. Adv Parasitol 2006;61:443-508.

4. Akalin S, Kutlu SS, Caylak SD, et al. Seroprevalence of human cystic echinococcosis and risk factors in animal breeders in rural communities in Denizli, Turkey. J Infect Dev Ctries 2014;8(9):1188-94.

5. Moro PL. Epidemiology and control of echinococcosis. Waltham, USA. UpToDate. Available: http://www.uptodate. com/contents/epidemiology-and-control-of-echinococcosis. Accessed: August 2013.

6. King CH, Fairley JK. Cestodes (Tapeworms). In: Mandell GL, Bennett JE, Dolin R, editors. Mandell, Douglas, and Bennett's Principles and Practice of Infectious Diseases, 7th edition. Philadelphia: Churchill Livingstone; 2010. p.3607-16.

7. Brunetti E, Kern P, Vuitton DA. Expert consensus for the diagnosis and treatment of cystic and alveolar echinococcosis in humans. Acta Trop 2010;114:1-16.

8. Stojkovic M, Rosenberger K, Kauczor HU, et al. Diagnosing and staging of cystic echinococcosis: how do CT and MRI perform in comparison to ultrasound? PLoS Negl Trop Dis 2012;6(10):e1880.

9. Piccoli L, Tamarozzi F, Cattaneo F, et al. Long-term Sonographic and Serological Follow-up of Inactive Echinococcal Cysts of the Liver: Hints for a "Watch-and-Wait" Approach. PLoS Negl Trop Dis 2014 Aug 14;8(8):e3057. 
10. Gharbi HA, Hassine W, Brauner MW, et al. Ultrasound examination of the hydatic liver 1981 May;139(2):459-63.

11. WHO Informal Working Group. International classification of ultrasound images in cystic echinococcosis for application in clinical and field epidemiological settings. Acta Trop 2003;85:253-61.

12. Saidi F. How to manage asymptomatic liver hydatids. Arch Iran Med 2006 Apr;9(2):173-4.

13. Smith SA, Richards KS. Ultrastructure and microanalyses of the calcareous corpuscles of the protoscoleces of Echinococcus granulosus. Parasitol Res 1993;79(3):245-50.

14. Yazar S, Ozkan AT, Hökelek M, et al. Cystic echinococcosis in Turkey from 2001-2005. Turkiye Parazitol Derg 2008;32(3):208-20.

15. Kayaalp C, Bzeizi K, Demirbag AE, et al. Biliary complications after hydatid liver surgery: incidence and risk factors. J Gastrointest Surg 2002 Sep-Oct;6(5):706-12.

16. Akkucuk S, Aydogan A, Ugur M, et al. Comparison of surgical procedures and percutaneous drainage in the treatment of liver hydatide cysts: a retrospective study in an endemic area. Int J Clin Exp Med 2014;7(8):2280-5.

17. Carabin H, Balsera-Rodríguez FJ, Rebollar-Sáenz J, et al. Cystic Echinococcosis in the Province of Alava, North Spain: The Monetary Burden of a Disease No Longer under Surveillance. PLoS Negl Trop Dis 2014 Aug 7;8(8).

18. Milicevic MN. Hydatid Disease, In: Blumgart LH, Fong Y, editors. Surgery of Liver and Biliary Tract. 3rd edition. London: WB Saunders Company; 2000. p.1167-204.

19. Moreno Gonzales E, Loinaz Sequrola C, Garcia Urena MA, et al. Liver transplantation for Echinococcosis granulosus hydatid disaese. Transplantation 1994;58:797.

20. Liance M, Janin V, Bresson-Hadni S, et al. Immunodiagnosis of Echinococcus infections: confirmatory testing and species differentiation by a new commercial Western Blot. J Clin Microbiol 2000 Oct;38(10):3718-21.

21. Safioleas M, Misiakos E, Manti C, et al. Diagnosis and treatment of hepatic hydatid disease of the liver. World J Surg 1994;18:859-63.
22. Adán Merino L, Alonso Gamarra E, Gómez Senent S, et al. Hidatidosis hepática: manejo actual de una entidada únpresente. Rev Esp Enferm Dig 2008;100:1130-48.

23. Salemis NS. Giant hydatid liver cyst. Management of residual cavity: A case report. Ann Hepatol 2008;7:174-6.

24. Giorgio A, de Stefano G, Di Sarno A, et al. Clinical and sonographic management of viable hydatid livercysts. J Ultrasound 2008 Sep;11(3):107-12.

25. Buttenschoen K, Schorcht P, Reuter S, et al. Surgicaltherapy of alveolar echinococcosis and long-term outcome. Chirurg 2001 May;72(5):566-72.

26. Sayek İ. Temel Cerrahi, 4. Baskı, Güneş Tıp Kitabevleri, Ankara 2010, Bölüm 136, s.1571-83.

27. Ben Amor N, Gargouri M, Gharbi HA, et al. Trial therapy of inoperable abdominal hydatid cysts by puncture. Ann Parasitol Hum Comp 1986;61(6):689-92.

28. Smego RA Jr, Sebanego P. Treatment options for hepatic cystic echinococcosis. Int J Infect Dis 2005 Mar;9(2):69-76.

29. Nasseri-Moghaddam S, Abrishami A, Taefi A, et al. Percutaneous needle aspiration, injection, and re-aspiration with or without benzimidazole coverage for uncomplicated hepatic hydatid cysts. Cochrane Database Syst Rev 2011 Jan 19;(1):CD003623.

30. Busić Z, Cupurdija K, Servis D, et al. Surgical treatment of liver echinococcosis -open or laparoscopic surgery? Coll Antropol 2012;36(4):1363-6.

31. Daradkeh S, El-Muhtaseb H, Farah G, et al. Predictors of morbidity and mortality in the surgical management of hydatidcyst of the liver. Langenbecks Arch Surg 2007 Jan;392(1):35-9.

32. Jerraya $H$, Khalfallah M, Osman SB, et al. Predictive factors of recurrence after surgical treatment for liver hydatid cyst. Surg Endosc 2014 Jun 25. [Epub ahead of print]

33. Elbir O, Gundogdu H, Caglikulekci M, et al. Surgical treatment of intrabiliary rupture of hydatid cysts of liver: comparison of choledochoduodenostomy with T-tube drainage. Dig Surg 2001;18(4):289-93. 